\title{
DivinATION AND ONTOLOGIES
}

\section{A Reflection}

David Zeitlyn

\begin{abstract}
The way types of divination move round the planet means it is not helpful to simply attribute one unitary ontology to specific techniques or to groups of practitioners. Explaining divination in terms of 'ontology' homogenizes cognitive and conceptual multiplicity, and pre-empts the possible outcomes of divination. Moreover, this contradicts the fundamentally open nature of divination, and the fact that in many forms of divination the reformulation of questions helps keep futures open. With examples drawn from Mambila spider divination, I suggest what an epidemiology of beliefs and ontologies that gather around divination could look like. On this account, divination acts as a 'boundary object', mediating both the cognitive differences among clients and the conceptual differences between clients and diviners.
\end{abstract}

Keywords: determinism, divinatory practice, Mambila spider divination, ontology, Schrödinger's spider

From the outside, it seems that many of those circling round the ontological turn seem to take for granted that anthropologists can recognize an ontology when they see, taste, or smell one and that no further definition is needed. However, turning to one of those closely associated with the creation of the turn, we find that 'these 'basic ideas' about the 'constitution of the world,' are quite similar to that which once got called, in the bad old days, 'cosmology,' 'ontology,' or even 'culture'” (Viveiros de Castro 2012: 66). I would add 'worldview' and 'mentality' to the list. In his introduction to this issue, William Matthews distinguishes explicit and deep forms of ontology. ${ }^{1}$ Matthews uses Michael Scott's term 'deep ontology' for analytical frameworks such as Descola's fourfold way, a characterization of the modes of reasoning found in ontologies (explicit or implicit). The articles in this issue are mainly concerned with explicit ontologies and 
the tracing of ontologies implicit in divinatory practice that in some cases are glossed as deep ontologies.

Overall, the individual articles draw on quite different types of ontology, even when discussing 'agentive' and 'calculatory' forms of divination, as suggested in the introduction. Indeed, the distinction between agentive and calculatory divination can be helpful without collocating with ontology. As Matthews points out, that distinction is explicit, and accordingly much of the discussion in the contributions to this special issue is at some remove from concerns about deep ontology.

To this commentator, divinatory praxis seems a far cry from any association of a singular ontology with a singular divinatory system, which is perhaps why discussion of ontologies does not seem to help explain how divination gets used. Although general discussion of ontology may offer the solution to all possible relativist problems, in practice it swaps one set of problems (e.g., about comprehending radical otherness) for others equally irresolvable (How many ontologies may one person have let alone one social group? If a diviner uses many techniques, are they part of many ontologies, one per divination type?). Better to stay with the trouble, to misuse Donna Haraway's (2016) title. 'Ontology' means too many different things to too many of the players, who just shift meanings in response to criticism. ${ }^{2}$ Even Holbraad and Pedersen (2017), writing as advocates of the turn, identify five variants, only one of which they promote. All of this raises doubts about whether we can meaningfully associate divination and ontology in general.

In the following, I discuss the problems of associating specific systems of divination with particular ontologies. Rather than as a secondary result of ontology, divination should be considered as an ongoing social process and a technology of translation. This is to view divination as a 'boundary object' (Star 2010; Star and Griesemer 1989), connecting clients (who often have immediate pressing concerns) with the diviners and the ontologies associated (if that is a sufficiently neutral term) with the type of divination being used. Boundary objects connect and simultaneously disconnect: they hold connections at a remove, in abeyance. So clients can consult divination without necessarily being a party to any ontologies that the diviners may associate with it.

\section{Does Divination Have an Ontology?}

The short answer to this straw question is simple: for 'divination' as a category, no. There is no single entity or concept that captures the enormous range of different mantic practices across the world (and across time), so there is no thing or idea that really can be said to have 'an ontology'. ${ }^{3}$ Of course, it might be entirely appropriate to talk about an individual divination system or practice as having 
or, better, being connected to or locally explained by an ontology. This is easiest to identify where there are explicit ontologies (whether calculatory or agentive) that may be referred to in explanation of how and why a form of divination produces authoritative results. However, it may also be appropriate for implicit divinatory ontologies. Where there are scattered hints, gestures, and throwaway comments that can be collated and that add up to some sort of account of how spirits or techniques can provide answers that can affect what will happen, then this could be described as this divination's ontology. As the articles in this special issue make clear, the use of divination often raises matters concerning forms of determinism and ideas about fate. These might plausibly be discussed in ontological terms. However, there is an important caution to consider: to talk of an individual divination system or practice as having an ontology is a shorthand, and sometimes shorthands can be misleading. It is not the divinatory system that has the ontology but the people who use it, or, to be more inclusive, the ensemble of practice formed by people and techniques/objects. For example, in different ways Swancutt's and Homola's articles in this issue illustrate the complexity of these entanglements in the variety of different techniques used and the way a single technique may be applied to different problems. Most of the time the practitioners and clients all concur and the shorthand is unproblematic, but this is not always the case. However, we must also recognize that not all the parties to divination may be part of a common shared ontology, as is made clear in some of the contributions to this issue (Homola, Simonetti, and Matthews). Even those that do talk of shared ontologies (Almqvist and Swancutt) leave room for doubt and variation in attitudes. There might be considerable heterogeneity within a community that ontology-talk obfuscates. The activity of consultation, divinatory praxis, may serve as a boundary object that enables the different parties to manage a lack of consensus.

Forms of divination move round the world, and both practitioners and clients move too, complicating the ways in which we might choose to connect ontologies and forms of divination. Cynics or evangelists may use divination in order to demonstrate to their brothers and sisters that the divination is 'false' (as they see it). Such phenomena make ascription of an ontology on the basis of divinatory praxis misleading, and we then have to make things more explicit at the risk of long-windedness. Consider the Yijing (I Ching), one of the oldest and most well-documented forms of divination in the world (see Matthews's introduction to this issue). If any type of divination deserves to 'have' an ontology, it is the Yijing. But as soon as one reflects on that statement, problems begin to accrue: Is there one Yijing ontology or many? Is there sufficient continuity with the ancient forms that we can speak of one ontology across time (centuries, millennia)? And how might the way it is used in one part of China relate to its use in another, thousands of kilometers away? For the Yijing, answers to these questions are possible. Matthews's work provides a clear account of the Chinese situation, both in 
contemporary China and across the historical period (see, e.g., Matthews 2017, 2018). In his view, the Yijing is built on some explicit ontological assumptions about $q i$ and the universe, ${ }^{4}$ which explains how acts of coin tossing, for example, can provide information about an individual's predicament. There is a further question: do differences in use affect the ontology that we could associate with a divinatory form such as the Yijing? In his contribution to this issue, Matthews argues as much. Moreover, such an emphasis on usage fits well with the differences in perspectives and individual interpretations illustrated in the articles by Homola, Swancutt, and Simonetti. When we widen the frame, however, the problems with ontologies compound and get murkier. Feuchtwang, in his commentary in this issue and in his recent co-authored monograph (Feuchtwang and Rowlands 2019), talks about stocks of imagery linking, or forming, civilizations. The patterns of transmission of such images can indeed be mapped and used to identify wider groupings (labeled as having 'shared ontologies' or 'common civilizations', depending on taste). Asking about the distribution of these images or of ontological themes-such as the agentive versus calculative distinction that frames many of the articles in this issue-raises a quite different set of issues that go back to Dan Sperber's (1990) idea of the epidemiology of belief, which could now be couched as ontological epidemiology.

To take a single example, searching the Internet for "I Ching London" (to get a UK perspective), the top hit on Google in mid-February 2020 was for Dr Karina Halstead's website, titled "The Art of Divination." Still a top hit at the present time, Halstead offers courses and consultations on "Astrology, Tarot \& The I Ching-The Book of Changes." Among the information offered on the I Ching courses (on the "About" page), she says that she has "Four decades of experience in consulting The I Ching or Book of Changes on all manner of questions: business, property, legal matters, people and cats. So, [sic] have plenty of informative and entertaining teaching material to share with those interested in this Ancient Book of Wisdom." This is absolutely not to criticize Dr Halstead but to raise doubts about whether the Yijing has a singular ontology since her usage is, as it were, at some remove from the Chinese tradition. I think that were she to collaborate with a researcher (or do the work herself in an auto-ethnographic fashion), it would be possible to characterize her use of different forms of divination and how she understands the world. This might plausibly be labeled an ontology. But whether the three systems she names on her website (astrology, tarot, I Ching) can straightforwardly be said to each have their own separate ontologies (whether implicit or explicit), frankly, I doubt. ${ }^{5}$ And even if they do, then I doubt even more whether those would help much in arriving at Halstead's ontology since they come from such different historical/cultural traditions. We can but speculate how much of the Confucianism associated with the Yijing might be found in Halstead's ontology. An explicit ontology in one place has become implicit in another. As I understand it, Confucianism sits 
uneasily ${ }^{6}$ with some of the forms of determinism associated with some forms of astrology, although professor dusky purples (2018: 280-281) shows what a misleading characterization this is. In his account of astrological practice, the point of consultation is all about fitting oneself to and with the universe, using contrasts between astrology and tarot reading to make narratives within which the querents (clients) can situate themselves. The ontological implications of such storytelling may be highly variable and may resist tidying into simple singular ontologies: the dangers of reification and misplaced concretism are ever present. Moreover this means that such ontologies cannot be elicited from diviners alone: what must be fully taken into account is the contribution of the clients to the process of narrativization. This means that anthropologists should not concentrate their attention on the diviners (practitioners) alone.

So much for practitioners. I shall now briefly consider the relationship of ontologies to clients, those seeking divinatory counsel. Many of the clients are likely to be in the gray area of the nevertheless captured by Octave Mannoni's phrase (1964) "je sais bien mais quand même" (I know very well but nevertheless), as discussed by Dominique Boullier (2004), or by quantum physicist Neils Bohr, who reported his neighbor saying that "horseshoes brought good luck even if you don't believe in them," a story told by Werner Heisenberg (1971: 92). Another way of thinking about this is to see it as falling within the pause, the moment of 'hesitation' identified by Bruno Latour (2001) when talking about religion. Such complexities are summarized by Kirstine Munk (2007) when discussing the use of astrology in northern Europe. She states: "Astrology is a tricky but typical example of modern non-institutionalized religion because there is no clear connection between belief and use. Some people believe in astrology but do not use it; others believe in it and use it, while others use it but do not believe in it" (ibid.: 288; italics in original). When clients come to a practitioner, or start to use divinatory techniques by themselves, it is not safe to assume or infer that they are agreeing to, participating in, buying into, acquiescing to, or co-constructing an ontology (readers will recognize that I am unsure what the best phrasing might be), that is, the ontology of that divinatory type.

Munk's quote above summarizes the situation nicely, not just for users of astrology, but for many users of many different divination systems. There are numerous ethnographies that stress the instrumentality of the way people consult. There are specific problems, and those afflicted will consider many options (often any options) that will help them resolve those problems. ${ }^{7}$ It is not clear to me that instrumental, pragmatic use is sufficient to warrant or to ascribe an ontology or ontologies. In other words (as William Matthews has pointed out to me), there are problems of ontology in anthropology that parallel recognized problems of 'belief'. It is easy when dealing with religious systems like Christianity, which have manuals that lay out beliefs to their followers and socially sanctioned experts to explain the texts. It is far less straightforward without 
texts or experts in similar positions of authority, or where the only recognized authorities are dead. ${ }^{8}$ This parallel seems clear for implicit and explicit ontologies. ${ }^{9}$ Reflecting on how people in rural France deal with affliction, and how her readers in the urban centers (including colleagues at the CNRS) empathize to the extent of asking for dewitching services, Jeanne Favret-Saada (2012) talks about 'minimal ontologies'.

\section{Anthropological Approaches to Divination}

I now turn to ways in which anthropologists have been (or, in my view, should be) studying divination and divinatory practice. The tensions between what people say they do and what they actually do are classical topics of anthropological interest. But given this background, it is odd that this difference has only rarely been addressed in the literature on divination, most of which is surprisingly idealized and abstracted from divinatory praxis. This leaves it difficult to understand the way that people maintain or perhaps change their perspectives as they live their lives.

Rather, we should accept that we necessarily give knowingly incomplete accounts of divination-and we should relish this. This is to entirely agree with Sónia Silva when discussing lipele basket divination among Luvale people on the Angola/Zambian border, neighbors of the Nbembu studied by Victor Turner (1975). Silva (2011: 141) states: "The view that lipele divination is a way of knowing, a way of doing, and a way of working and laboring is incomplete." In a series of later articles, Silva uses basket divination as the basis for understanding the religious system of the people concerned (see Silva 2013, 2014, 2018). Contrastingly, I have found that the study of Mambila divination helps to understand the sociology of the clients more than their religion. However, by presenting a knowingly incomplete account, I leave room for other Mambila scholars to undertake more research on Mambila religion (see Zeitlyn 2020b).

My interest in what clients use divination for and how they (rather than the experts) make sense of the results puts me at odds with scholars intent on extracting ontologies from the study of divination. Such scholars are interested in cosmology and meaning and are wary, as René Devisch (2012: 94) puts it, of any reduction to "pragmatic enactment of the order of facts." But this is not a zero-sum game. Rather than a reduction to pragmatics, I suggest that we examine how facts are made pragmatically, and rather than the religio-semiotic systems of the diviners, I concentrate on the clients' perspectives. These different emphases are, perhaps surprisingly, disconnected from each other; at the very least, they underdetermine each other. Often this is sustained by forms of an intellectual division of labor facilitated by the divinatory process that everyone concentrates on (and possibly talks about), but potentially in different ways. 
This is why it can function as a boundary object. Knowledge about cosmological meanings in the abstract tells us little about how their application can help an individual to resolve a real-life problem, just as individual cases offer relatively little help in unpacking an ontology. To take an example from EvansPritchard's (1937) classic anthropological analysis of divination, an account of Zande ontology would surely include the way that humans can attack each other through witchcraft and that the power to do so is inherited matrilaterally. However, to understand how ideas about witchcraft are used to explain and address misfortune, a detail becomes important, one that I do not think would be granted the same status in the Zande ontology as the two features already given-inherited witchcraft potential may not be active. In other words, it cannot be inferred without evidence (e.g., from divination) that the children of a known witch are bewitching their enemies. What we need are multiple ways of thinking through ethnographic complexity.

\section{Divination as a Decision-Making Technology}

Another way of framing these issues is by seeing divination as a technology of decision making. Writing in the United States for a range of individuals in various sectors, Adam Gordon (2008: 211) says that "the test of this forecasting is not a more accurate picture of tomorrow, but better thinking about the future. The payoff is better decisions, not better predictions." His book targets market makers and advertising agents who aspire to future-influencing actions rather than neutral predictions or forecasts. However, what counts as "better thinking about the future" is highly contentious and is perhaps the most important first question. That there is no single (let alone simple) answer itself has implications about how to approach "thinking about the future" (see Zeitlyn 2020a for other ways of doing this). The different forms of divination and the highly disparate ways in which they are used can illuminate the ways different people think about the future (among other things). ${ }^{10}$ And, as was mentioned above, when analyzing actual processes of forecasting or divining, it may help to approach them as sequences of putative translations, or discussions of suggested translations. The procedures and technicalities of divinatory praxis may feature in these discussions as boundary objects, having very different resonances to clients and to diviners who nonetheless are able to continue their interactions, in part through their mutual orientation to the divination being undertaken.

It may be more accurate to think of divination as a technology that assists decision making, or is at least involved in decision making. As several large literatures have made clear, 'decision making' is not a straightforward process: it is deeply misleading to think of it as occurring by formulaic means, let alone through the cool application of rationality or formal logic. The historian Ged 
Martin (2004) provides some excellent examples of how hard it is to pin down what led to a decision being made in the way it was (i.e., the processes of decision making), particularly when it is retrospectively recast after the fact as having taken place according to a hard rationalist logic. He cites the telling example of British author and activist Edith Lyttelton, who spent time in 1900 debating whether to follow her husband to South Africa or whether to stay in the UK with her two-month-old baby. Despite finding many good reasons to stay, she awoke one morning to find that she had decided to leave (ibid.: 87).

This has been taken up recently in very different terms by Pascal Boyer (2020). He argues that divination is persuasive because the techniques used are seen to justify the utterances made as not being the responsibility of the diviner: the techniques remove diviners from responsibility for authorship of the results, thereby making them disinterested parties. ${ }^{11}$ As well as avoiding reasons to distrust the results, divination provides an external means of breaking a deadlock to overcome what Jean-Pierre Boutinet (1990: 337) calls "the anguish of an uncertain future." As G. E. R. Lloyd (2002: 41) puts it, "the chief role of a prediction may ... simply [be] to resolve indecision." 12

Many authors have made similar points about the use of divination. These include Sarah Iles Johnston (2005), who discusses ancient divination as not "a way of solving a particular problem ... but rather a way of redirecting the problem" (ibid.: 22; emphasis in original), so that it can be solved by human or everyday means. Also discussing ancient oracles, in this case in Roman Egypt, David Ratzan (2018) argues that one effect of using divination was to overcome distrust and so facilitate long-distance trade.

In his account of Chinese geomancy, Stephan Feuchtwang (2002: 279) writes that one of its functions is "to regularise the making of decisions in an irregular and uncertain field of choice” (see also Stafford 2007). A similar sentiment is ascribed by Michael Jackson (2013: 44-45) to Kuranko life-worlds in Sierra Leone: “The diviner's analysis transforms uncertainty into a provisional certainty, and his instructions for an appropriate sacrifice enable the consulter to move from inertia to purposeful activity (praxis)." Jackson uses a phenomenological, experiential approach that avoids talk of ontological difference, relying instead on his ethnographic involvement in the life of the Kuranko village of Kamadugu Sukurela.

As well as enabling action by externalizing the source of the decision and thereby avoiding potentially endless prevarication, the source of divinatory advice (which, as noted, is usually not seen to be the diviner) is invested with responsibility for decisions. Paralleling the way Boyer argues that diviners are not responsible for their utterances, the clients can also say that they are not responsible for their decisions-they are, as it were, 'just following orders'. What Boyer calls 'ostensive detachment' thus has cosmological and ontological implications, as the contributors to this special issue show in so many ways. 
Yet the question remains, what sorts of entities can be held responsible? Attributions of responsibility emerge from what Hirokazu Miyazaki (2003: 259) calls "an anticipation of retrospection," a term elaborated on by Carlo Caduff (2014: 303). The two strands of decision making and responsibility for actions combine, so that "divination comes into view as a cultural technology of hope and prospect, reshaping and recreating the temporal horizon of the individual subject” (Graw 2012: 25).

\section{Skepticism beyond Academia}

Several authors, from Evans-Pritchard onward, have described widespread unease among groups using divination about whether particular diviners are charlatans. Evans-Pritchard (1937: 185) reports that many of his Azande acquaintances "believed that there are a few reliable practitioners, but that the majority are quacks." This led to his much-discussed list of 22 reasons "why the Zande do not perceive the futility of their magic” (ibid.: 475-478). Words such as 'futility', 'quack', and 'charlatan' are of course highly pejorative. I prefer to tread a different path, not so much ducking these issues as addressing them obliquely (in the spirit of Emily Dickinson's telling the truth 'slant') in the hope of avoiding the need to use such contentious language or to ask the questions that often elicit it.

Related to skepticism is the widespread phenomenon of mundane empiricism. This can be demonstrated by two quotations from the literature on divination in Africa:

There is in the client if not in the diviner a willing suspension of belief ... But the object of a drama lies in its production of an intelligence applicable beyond itself. The only requirement is that the drama should not break down before the epiphanies are achieved. That such a dramatic production as divination is not easily brought off, however, is evidenced by the considerable amount of shopping around by clients for suitable diviners (Fernandez 1967: 17).

Not only the diviners but also the clients have their own strategies. For the clients, withholding information is a crucial means not only of testing the diviner but also of minimizing the influence of the clever smiths, for clients want to retain as much agency as possible. Although they trust his performance and the profession, at least to some extent, they frequently choose to get a second opinion, sometimes right after a certain treatment has been recommended (van Beek 2015: 146-147).

In her account of Gisu divination in Uganda, whose diviners operate only in private and never produce certain results, Suzette Heald (1991: 305) describes clients as being wary of what could be described as 'cold calling'13 by diviners. They prefer to consult distant diviners who do not know about their case. She points to the need to pay heed to the "sessions which end as they began, 
indeterminate as to causal agent and to the procedure to be followed"-the 'unsuccessful' consultations (ibid.: 306). For an individual to be identified as a witch, Heald says, three independent diviners must concur. This reveals the limited authority ascribed to a single diviner. She also questions the adequacy of a functionalist approach, emphasizing positive, socially redemptive dispute resolution, whereas she sees unending conflict: "When divination-as is often, perhaps even usually, the case-provides no clear course of action the suspicions entertained remain to be hidden in the heart until the next misfortune brings them back into play and into full consciousness once more. Divination here legitimatises ill will" (ibid.: 313). She quotes Turner for whom divination revealed "a 'paranoid' style, plugged into a negative vision of social reality, the 'secret war of all against all'" (ibid.). So discussion of skepticism shades into discussion of the zero-sum game of witchcraft as exemplifying the play of individual competition.

We must also recognize that what appears to be skeptical behavior may not be evidence of skepticism. Aaron Denham (2017) has discussed Nankani divination in northern Ghana, a system similar to that of the Tallensi described and filmed by Meyer Fortes $(1959,1966)$. Nankani clients behave in ways that might be associated with skepticism, such as undertaking repeated consultations with different diviners. They also use an extreme masking technique, sending a relative to deliver two sticks to a distant diviner and ask which of the two alternatives is correct, without telling either relative or diviner which alternative is associated with which stick (Denham 2017: 109-110). However, this technique ${ }^{14}$ is said to be used not to avoid charlatan diviners but to prevent spirit children from interfering with the results.

\section{Taking Clients Seriously?}

Divination in the abstract may have many meanings for different groups of people and, as I said above, does not have a single, identifiable ontology. It may have different meanings in theory for scholars-as a set of ideas, as a symbolic system for its practitioners-while clients may be more interested in the results of consulting divination regardless of its symbolic or cosmological implications (which they leave to those with the luxury to consider them). From the clients' perspective the pragmatics of decision making, the ubiquitous need to make decisions in the context of doubt and uncertainty, does not gain from there being a single cosmological or ontological blueprint realized in divination. As practiced divination is something else again, it is many other things, and is perhaps not best thought about primarily in terms of 'meanings' or as a symbolic system. ${ }^{15}$ In practice, and especially for clients, it is a mechanism to test ways of understanding a situation and to help people confronting 
problems, often complicated and sometimes conflicting, to decide on the best way to react to them.

I have sought to address this by encompassing partial views, using a variety of perspectives (see Zeitlyn 2020b). I see an acceptance of incompleteness as a strength of social anthropology (Zeitlyn 2008; Zeitlyn and Just 2014; see also Nyamnjoh 2017: 120-121), since this provides a framework for accommodating inconsistent approaches. At one level of analysis, the forms of divination being used are consistent with its social functions. I emphasize the modesty of the phrase "consistent with its social functions." The social role of divination alone cannot provide a full functional explanation (after Elster 1982). However, the constraints of social function cannot be ignored, and, weak though they are, those constraints explain some of what is found, ruling out other outcomes. We cannot explain in these terms why the phenomenon exists at all, let alone the details of a particular type of divination; but given that it does exist, its persistence (in that social role) may be so explained. The reasons for the existence of any social feature are historical in the most general sense of the word. The institution may have been borrowed, bought, invented, imposed, or otherwise introduced. The literature on witchcraft eradication movements gives good examples of the historical dynamics concerned (see, e.g., Bonhomme 2013; Douglas 1963; Willis 1970).

In what ways can we move beyond this? Some form of 'cognitive process' is taking place since the people practicing divination (clients as well as diviners) are literally thinking through problems. ${ }^{16}$ So divination can be used as a natural laboratory for those interested in cognition 'in the wild'. Notwithstanding this, another avenue of research concerns the problems themselves and what they tell us about clients' lives, insofar as these can be separated from the cognition involved in thinking about them.

Different types of divination can be distinguished. ${ }^{17}$ Using the terms introduced by Matthews for this issue, on the one hand is 'agentive divination', in which the warrants for the truth of the divinatory utterances lie with agents other than the diviner (often but not always associated with the diviner being possessed by those agents). On the other is 'calculatory divination', in which the procedures (techniques) of divination must be correctly performed. Correct practice is held to be necessary to obtain truthful divinatory utterances in calculatory divination. This gives such forms of divination a multiple orientation (making it an attractive subject for social anthropologists), as they require the diviner to look toward (1) the process of divination, that is, the procedures and techniques that constitute divinatory practice, whereby the calculations must be performed correctly; (2) the audience, which sometimes includes other diviners, anthropologists, and potential clients; and (3) the client who brings a problem, a question, or a set of inquiries to the divinatory séance. Clients must be satisfied that their concerns have been addressed and their questions answered. ${ }^{18}$ 
Since diviners must demonstrate technical or professional competence as well as providing answers to the client's problems, close study of divination can reveal thought in action. Approaches from conversation analysis and (more generally) ethno-methodology can be of assistance here. Works by Harold Garfinkel ([1967] 1984) and Peter McHugh (1968) point up the significance of responses to contradictions that I have applied to divinatory process (Zeitlyn 1990, 2020b).

As mentioned above, divination renders cognition concrete or explicit. This makes the work of researchers such as Edwin Hutchins (1994) and Eric Livingston (2008), who pioneered the study of rationality 'in the wild', highly relevant to the study of divination. However, the course of fieldwork has led me to a different and very old set of anthropological preoccupations, concerned less with the mode or style of reasoning and more with the patterns of the issues at stake. This is to use the study of divination cases as an anthropological or even as a sociological lens, providing an account of local social concerns. Cognition remains relevant, since it is never possible to stop thinking. Divination can reveal both the topics that are of most concern in a social group and how clients using divination think through those topics as they decide what to do next. Livingston has demonstrated that reasoning may work differently for different tasks: addressing a problem in checkers (draughts), doing a jigsaw puzzle, or using a domestic fridge (ibid.). These empirical observations are particularly important in rebutting philosophers who, over the centuries and with no empirical basis, have asserted or merely assumed the existence of only one form of rationality: logic. It is reasonable to infer that people may reason differently about the principles of divination than about weeding their fields. Even when consulting divination, they may reason differently about results concerning the serious illness of a child than about those concerning missing goats, as I hope researchers will explore in future. ${ }^{19}$

I have compiled a data set of more than 600 cases of Mambila divinatory consultation. This allows us to summarize the pattern of Mambila concerns, the distribution of question types revealing a sociology of troubles and uncertainties. It also allows us to examine the boundary between anticipation and prediction, between people's attitudes to the near and the far future. Mambila divination clients tend to bring questions about immediate problems, things that can be clearly anticipated, rather than longer-term predictive concerns. For example, a client from a neighboring village asked (on 29 August 2012) about taking professional examinations and was told to wait until the following year. Someone asking about building a house was also told (on 5 July 2013) to wait a year (house building only takes place during the dry season):

Q: $[\mathrm{XXX}\}$ came to ask about building a house. He wants to do it this year or should he wait?

A: He should wait until next year. 
However, this temporal distinction masks the way that short-term issues can become persistent. In 1985, one of the first divination sessions I was allowed to record concerned the ill health of the client's daughter. She recovered from the malaria that was then the immediate issue, but sadly in 2019 her chronic eczema persisted. With hindsight (retrodiction) we can see that what had been immediate short-term problems have now become long-term ones. The question that is never asked is the general one: will I resolve this problem? A negative answer would deny hope. There is always hope, so the question is not asked. A senior diviner discussed these issues with me in the pauses during a consultation with another diviner while we waited for the spiders to emerge and provide their answers. He was clear that when divining about an illness, one does not ask, "Will this person die?" The flow of our conversation turned him into a determinist - a case of what Baruch Fischhoff and Ruth Beyth (1975) would call 'creeping determinism'-retrospectively ascribing events with inevitability. For him, "divination does not lie," so if it says "someone will die," then they will die. ${ }^{20}$ But he is not a hard-nosed determinist (except when discussion with an anthropologist makes him so), holding that if you do not ask the question, then the possibility of recovery remains. From that viewpoint, the divinatory process seems to fix the outcome: to force an issue by asking the question rules out options that would have been left open by avoidance of the question. There are delicate issues of translation at play in the way that the impetus to consult divination leads to the actual framing of questions. In the example of this illness, recovery remained an option as long as it was not ruled out by asking about it. In other words, implicit in the question is the 'horizon of expectation' (Koselleck [1985] 2004) that encompasses possible answers. So the options put to divination enable us to sketch the bounds of possibility, the sense of what is possible that is demonstrably shared by the speakers. The alternatives they propose are accepted as viable and are literally unquestioned, and hence come to form the backdrop to the consultation, its 'horizon of expectation'.

Returning to the avoidance of asking whether someone might die, this aspect of question framing suggests a Mambila version of Schrödinger's cat, the quantum physics thought experiment in which a cat sits in a limbo of superposed possibilities, being both dead and alive, until the act of inspection collapses the 'wave packet', bringing about one state or the other. However, in the Mambila version the superposed state would end not when the box was opened but when the possibility of death was posed to and ruled on by spider divination. In such a case, a Mambila diviner might say that the spider had opened the box behind the scenes and reported what it found. A Mambila version of the thought experiment might perhaps be better called Schrödinger's spider.

The notion that divination affects outcomes has interesting and perplexing implications. It allows Mambila clients some say in how far their future is fixed. By not divining, or by divining but choosing their questions so as to 
leave positive outcomes in play, they keep their futures more open, choosing among translations of their problems as they pose (frame) questions. So for Mambila clients, the play of anticipation as it shades into longer-term prediction is controlled and managed, even if not described as such. The contributors to this special issue describe the fundamental assumptions that structure anticipation as ontologies at the risk of misplaced concretism. ${ }^{21}$ Such concretism makes it difficult to capture the variation of opinions and perspectives in Mambila spider divination, for instance. Differences of opinion and lack of consensus can be managed by the use of boundary objects, technologies such as divination that allow people to meet and act together without going into detail or discussing whether or not they share an ontology.

\section{Conclusions}

Although the questions reveal the bounds of possibility being considered, it is important to remain alert to the questions not being asked, not because they are unthinkable but because they are unpalatable. The UK's Chancellor of the Exchequer Philip Hammond was in the news in October 2017 for not making contingency plans for a 'hard Brexit'. It was probably not that he could not anticipate that outcome and more likely that he did not want to make that possibility seem more real by planning for it (little more than two years later the irony of this is already apparent). We make our futures not only by the choices we make but, before then, by the outcomes we contemplate, by the patterns of our multiple anticipations. For this reason, the way questions are framed, the outcomes they include or exclude, and the background circumstances they take for granted or reject out of hand deserve further study.

There is an increasing amount of scholarship on differing conceptualization of fate and destiny (see, e.g., Elliot 2016; Elliot and Menin 2018; Menin 2015). Living in and with uncertainty makes futures 'uncanny', as Bryant and Knight (2019) put it, and if 'the future is written', then it is not clear who can read the text or whether it can be revised. This increases demand for divination and other means to deal with opaque futures. If diviners are seen as those who can read 'what is written', how can clients be sure that they will read correctly, let alone understand what they have read? And the text that they read may in fact be a palimpsest, so a 'reading' may not help those who must decide how to act without interpretative work being done by all involved (once again this involves forms of translation). As Samuli Schielke (2018: 343) puts it: “This 'malleable fixity' ... has made destiny an extraordinarily helpful idea for humans to find their way in a life that they live but do not own."

The study of divination can provide privileged insights into the way people deal with the multiple and intertwining problems posed by everyday life. 
The questions asked and the ways in which alternatives are framed reveal the bounds of conceptual possibility (which could be glossed as an ontology) in terms of which people reason when deciding what their actions should be. The clients may not have elaborated some of these ideas as much as the diviners, who are often intellectuals: in other words, there may not be a common ontology connecting the participants. But when they meet in a divinatory consultation, diviner and client need to connect somehow or other. This may be through a (somewhat) shared understanding, or by the divinatory praxis acting as a boundary object, which the diviners and clients use to talk across or talk through. On this account it matters little whether the divination system being used is agentive or calculatory. Whatever the means used in the triangular interaction between divination, diviners, and clients, the clients must leave feeling that their issues have been (more or less) addressed, or they will not return. For too long, the key divinatory encounter for academics such as anthropologists has been that between anthropologist and diviner. Such encounters can easily lead to anthropologists generating ontologies. It is time we recognize that the encounter that matters is that between diviner and client-and that these encounters do not need a common ontology to be deemed successful.

\section{Acknowledgments}

I am very grateful to the participants of the workshop at LSE for the encouraging discussion on divination and for the comments on the draft article. William Matthews and Hans Steinmüller have made the process of turning workshop comments into a more formal article as painless as possible and an enjoyable process of developing an argument.

David Zeitlyn has been working with Mambila people in Cameroon since 1985. He taught at the University of Kent, Canterbury, for 15 years before moving to Oxford in 2010. His research covers religion, socio-linguistics, and vernacular photography. Spider divination has been a recurrent topic that has been tackled in several different ways as reflected in his book Mambila Divination: Framing Questions, Constructing Answers (2020). Other recent publications include Visual Methods in Social Research (2015, 2nd ed.), with Marcus Banks, and Excursions in Realist Anthropology: A Merological Approach (2014), with Roger Just. A theory book, An Anthropological Toolkit: Sixty Useful Concepts, will be published by Berghahn Books in 2022. E-mail: david.zeitlyn@anthro.ox.ac.uk 


\section{Notes}

1. Deep ontologies are also intuitive. Pascal Boyer (1999) uses the latter term when discussing the cognitive foundations of religion. He contrasts "religious ontologies, that is, mental representations concerning the existence (and causal powers) of various supernatural entities" (ibid.: 55; author's emphasis) with 'intuitive ontologies' acquired in childhood about how the world works (e.g., whether trees walk and think or if stones speak).

2. See, for example, Pedersen (2012) for a master class in such deft footwork.

3. By and large, I will leave as a different issue for others to pursue whether things/ idea/practices should be talked about as 'having' ontologies at all, although some initial thoughts follow. I have discussed other problems with ontologies elsewhere (Zeitlyn 2014). There is now a large literature discussing the pros and cons of the ontological turn. A starting point is the GDAT debate from 2008 published as "Ontology Is Just Another Word for Culture” (Carrithers et al. 2010).

4. Other forms of divination may not be accompanied by such explicit theorizing: neither tarot cards nor Mambila spider divination seem to have it.

5. As we have seen, for the Yijing an ontology can be identified, for tarot it is unclear (to be generous), and for astrology there are several competitors. What then are the ontological commitments of someone like Dr Halstead who uses all three?

6. Without getting further embroiled in speculation upon speculation, I note that these comments assume that an ontology should be self-consistent. I am not sure that this is correct. I leave neo-ontologians to tease out the implications of the possibilities of contradictory or inconsistent ontologies. What is inconsistent on paper (e.g., in an anthropologist's systematization) may nonetheless be consistent and entirely workable in practice.

7. See the discussion of Boyer (2020) below for why people find divinatory results authoritative.

8. See, for example, Zeitlyn (1994: 240-244) for a Mambila instance of these beliefs.

9. For deep ontologies, the situation may be worse. Once again we have the specter of the anthropologist claiming to know more than the people whose ontologies these are. The problem of structures identified by Lévi-Strauss through comparative analysis of Amerindian mythology also holds for Descola.

10. I discuss various models for this in a recent article in Current Anthropology (see Zeitlyn 2020a). Bryant and Knight (2019) give another approach concentrating on those caught in unending presents whose futures may not arise. A useful way of characterizing various forms of temporal thought is via Bakhtin's (1981) idea of the chronotope. A chronotope connects attitudes to space and time, so different cultural traditions may have different chronotopes.

11. Similar arguments have been made by Du Bois (1987) and then by Zempléni (1994); however, Boyer (2020) puts the arguments in a wider, more evolutionary frame.

12. This is implicit in Niklas Luhmann's (2006) ideas about 'uncertainty reduction' or 'uncertainty absorption'. 
13. This is a pejorative term for the practice of many stage psychics in which information is elicited and then reported to the audience without the elicitation being noticed.

14. Versions of this same technique are known from the classical world. See Johnston (2008: 68) regarding instances from the oracle at Dodona.

15. A concern with 'meaning' risks sending anthropologists down the path of theological abstraction, perhaps working with like-minded diviners to construct an elaborate ontology, making the implicit explicit in ways not normally done. This is 'situation normal' for a lot of anthropology with its considerable and well-recognized attendant dangers of reification and overformalization. These are comfortable concerns for intellectuals removed from the mundane urgency that leads many to consult divination, such as the questions of how to treat an illness and who should do it.

16. The ambiguity of this phrase is fortuitous and has been left to stand.

17. Discussion of possible classifications goes back to Cicero. See Zeitlyn (2020b: chap. 2) for a summary.

18. Even if clients are unhappy about the results, they must accept them as answers to the questions posed.

19. Aafke de Vos's (2017) thesis uses inferential erotetic logic (IEL) to formalize some instances of Mambila divination, but her data set (extracted from my unpublished data) is not large enough to be able to consider possible differences in reasoning between different topics. For now, all we can do is point to the possibility and the way that divination studies provide a natural laboratory for studies of reasoning.

20. This resembles Martin Holbraad's (2012) account of Ifá divination in Cuba. The Mambila twist is that they tend to avoid the fixity described.

21. Commenting on a draft, William Matthews asked, "Does ontology have to imply uniformity of ideas between individuals?" It is not for me to answer this question, but if the answer is that there is no "uniformity of ideas," then I cannot really see how there can be a single ontology. And if we are multiplying ontologies among members of a single social group, then I fear the idea loses utility (to put it politely). However, I note that Matthews sees virtue in the epidemiological ontological approaches mentioned earlier, but does not share my worry that this risks multiplying ontologies too much to be helpful.

\section{References}

Bakhtin, Mikhail Mikhailovich. 1981. "Forms of Time and of the Chronotope in the Novel: Notes toward a Historical Poetics.” In The Dialogic Imagination: Four Essays, ed. Michael Holquist; trans. Caryl Emerson and Michael Holquist, 84-258. Austin: University of Texas Press.

Bonhomme, Julien. 2013. "Antiwitchcraft Movements in Africa." In The WileyBlackwell Encyclopedia of Social and Political Movements, ed. David A. Snow, 
Donatella della Porta, Bert Klandermans, and Doug McAdam, 319-345. Oxford: Wiley-Blackwell.

Boullier, Dominique. 2004. "Au-delà de la croyance: 'Je sais bien mais quand même'” [Beyond belief: 'I know very well but nevertheless']. Cosmopolitiques 6: $27-47$.

Boutinet, Jean-Pierre. 1990. Anthropologie du projet [Anthropology of the project]. Paris: Presses Universitaires de France.

Boyer, Pascal. 1999. "Cognitive Aspects of Religious Ontologies: How Brain Processes Constrain Religious Concepts.” Scripta Instituti Donneriani Aboensis 17 (1): 53-72.

Boyer, Pascal. 2020. "Why Divination? Evolved Psychology and Strategic Interaction in the Production of Truth." Current Anthropology 61 (1): 100-123.

Bryant, Rebecca, and Daniel M. Knight. 2019. The Anthropology of the Future. Cambridge: Cambridge University Press.

Caduff, Carlo. 2014. "Pandemic Prophecy, or How to Have Faith in Reason." Current Anthropology 55 (3): 296-315. https://doi.org/10.1086/676124.

Carrithers, Michael, Matei Candea, Karen Sykes, Martin Holbraad, and Soumhya Venkatesan. 2010. “Ontology Is Just Another Word for Culture: Motion Tabled at the 2008 Meeting of the Group for Debates in Anthropological Theory (GDAT), University of Manchester.” Critique of Anthropology 30 (2): 152-200. https://doi.org/10.1177/0308275X09364070.

de Vos, Aafke. 2017. “The Logic of Divinatory Reasoning.” MSc thesis, University of Amsterdam.

Denham, Aaron R. 2017. Spirit Children: Illness, Poverty, and Infanticide in Northern Ghana. Madison: University of Wisconsin Press.

Devisch, René. 2012. "Divination in Africa: The Bodiliness of Acute Discernment." In The Wiley-Blackwell Companion to African Religions, ed. Elias Kifon Bongmba, 79-96. Oxford: Wiley-Blackwell.

Douglas, Mary. 1963. “Techniques of Sorcery Control in Central Africa.” In Witchcraft and Sorcery in East Africa, ed. John Middleton and E. H. Winter, 123-142. London: Routledge \& Kegan Paul.

Du Bois, John W. 1987. "Meaning without Intention: Lessons from Divination." IPrA Papers in Pragmatics 1 (2): 80-122.

Elliot, Alice. 2016. "The Makeup of Destiny: Predestination and the Labor of Hope in a Moroccan Emigrant Town.” American Ethnologist 43 (3): 488-499. https:// doi.org/10.1111/amet.12341.

Elliot, Alice, and Laura Menin. 2018. "For an Anthropology of Destiny." HAU: Journal of Ethnographic Theory 8 (1-2): 292-299. https://doi.org/10.1086/698223.

Elster, Jon. 1982. Explaining Technical Change: A Case Study in the Philosophy of Science. Cambridge: Cambridge University Press.

Evans-Pritchard, E. E. 1937. Witchcraft, Oracles and Magic among the Azande. Oxford: Clarendon Press.

Favret-Saada, Jeanne. 2012. "Death at Your Heels: When Ethnographic Writing Propagates the Force of Witchcraft." HAU: Journal of Ethnographic Theory 2 (1): 45-53. https://doi.org/10.14318/hau2.1.004. 
Fernandez, James W. 1967. "Divinations, Confessions, Testimonies-Confrontations with the Social Superstructure among Durban Africans.” Occasional Papers of the Institute for Social Research (Winter-Spring) No. 9, University of Natal (Durban).

Feuchtwang, Stephan. 2002. An Anthropological Analysis of Chinese Geomancy. Bangkok: White Lotus Press.

Feuchtwang, Stephan, and Michael Rowlands. 2019. Civilisation Recast: Theoretical and Historical Perspectives. Cambridge: Cambridge University Press.

Fischhoff, Baruch, and Ruth Beyth. 1975. "I Knew It Would Happen: Remembered Probabilities of Once-Future Things." Organizational Behavior and Human Performance 13 (1): 1-16. https://doi.org/10.1016/0030-5073(75)90002-1.

Fortes, Meyer. 1959. "Divination among the Tallensi.” Paper prepared for seminar in processes of religious organization, 2 June.

Fortes, Meyer. 1966. "Religious Premisses and Logical Technique in Divinatory Ritual.” Philosophical Transactions of the Royal Society of London 251 (772): 409-422.

Garfinkel, Harold. (1967) 1984. “Common Sense Knowledge of Social Structures: The Documentary Method of Interpretation in Lay and Professional Fact Finding.” In Studies in Ethnomethodology, 76-103. Cambridge: Polity Press.

Gordon, Adam. 2008. Future Savvy: Identifying Trends to Make Better Decisions, Manage Uncertainty, and Profit from Change. New York: AMACOM.

Graw, Knut. 2012. "Divination and Islam: Existential Perspectives in the Study of Ritual and Religious Praxis in Senegal and Gambia.” In Ordinary Lives and Grand Schemes: An Anthropology of Everyday Religion, ed. Samuli Schielke and Liza Debevec, 17-32. New York: Berghahn Books.

Haraway, Donna J. 2016. Staying with the Trouble: Making Kin in the Chthulucene. Durham, NC: Duke University Press.

Heald, Suzette. 1991. "Divinatory Failure: The Religious and Social Role of Gisu Diviners.” Africa 61 (3): 299-317. https://doi.org/10.2307/1160026.

Heisenberg, Werner. 1971. Physics and Beyond: Encounters and Conversations. Trans. Arnold J. Pomerans. New York: Harper \& Row.

Holbraad, Martin. 2012. "Truth beyond Doubt: Ifá Oracles in Havana.” HAU: Journal of Ethnographic Theory 2 (1): 81-109. https://doi.org/10.14318/ hau2.1.006.

Holbraad, Martin, and Morten Axel Pedersen. 2017. The Ontological Turn: An Anthropological Exposition. Cambridge: Cambridge University Press.

Hutchins, Edwin. 1994. Cognition in the Wild. Cambridge, MA: MIT Press.

Jackson, Michael. 2013. Lifeworlds: Essays in Existential Anthropology. Chicago: University of Chicago Press.

Johnston, Sarah Iles. 2005. “Introduction: Divining Divination.” In Mantikê: Studies in Ancient Divination, ed. Sarah Iles Johnston and Peter T. Struck, 1-28. Leiden: Brill.

Johnston, Sarah Iles. 2008. Ancient Greek Divination. Oxford: Wiley-Blackwell. Koselleck, Reinhart. (1985) 2004. Futures Past: On the Semantics of Historical Time. Trans. Keith Tribe. New York: Columbia University Press. 
Latour, Bruno. 2001. “"Thou Shalt Not Take the Lord's Name in Vain”: Being a Sort of Sermon on the Hesitations of Religious Speech.” RES: Anthropology and Ethics 39: 215-234.

Livingston, Eric. 2008. Ethnographies of Reason. Aldershot: Ashgate.

Lloyd, G. E. R. 2002. “The Modalities of Prediction.” In The Ambitions of Curiosity: Understanding the World in Ancient Greece and China, 21-43. Cambridge: Cambridge University Press.

Luhmann, Niklas. 2006. “The Paradox of Decision Making.” In Niklas Luhmann and Organization Studies, ed. David Seidl and Kai Helge Becker, 85-106. Copenhagen: Copenhagen Business School Press.

Mannoni, Octave. 1964. "Je sais bien mais quand même” [I know very well but nevertheless]. Les Temps modernes 212: 9-33.

Martin, Ged. 2004. Past Futures: The Impossible Necessity of History. Toronto: University of Toronto Press.

Matthews, William. 2017. "Ontology with Chinese Characteristics: Homology as a Mode of Identification.” HAU: Journal of Ethnographic Theory 7 (1): 265-285. https://doi.org/10.14318/hau7.1.020.

Matthews, William. 2018. "Encompassing the Horse: Analogy, Category, and Scale in the Yijing.” British Journal of Chinese Studies 8 (1): 32-61. https://doi. org/10.51661/bjocs.v8i1.19.

McHugh, Peter. 1968. Defining the Situation: The Organization of Meaning in Social Interaction. New York: Bobbs-Merrill.

Menin, Laura. 2015. “The Impasse of Modernity: Personal Agency, Divine Destiny, and the Unpredictability of Intimate Relationships in Morocco." Journal of the Royal Anthropological Institute 21 (4): 892-910. https://doi. org/10.1111/1467-9655.12293.

Miyazaki, Hirokazu. 2003. "The Temporalities of the Market." American Anthropologist 105 (2): 255-265. https://doi.org/10.1525/aa.2003.105.2.255.

Munk, Kirstine. 2007. "Signs of the Times: Cosmology and Ritual Practice in Modern, Western Astrology.” PhD diss., University of Southern Denmark. https://www.yumpu.com/en/document/view/13650970/ signs-of-the-times-phd-kirstine-munk-bisbo-astrology.

Nyamnjoh, Francis B. 2017. Drinking from the Cosmic Gourd: How Amos Tutuola Can Change Our Minds. Oxford: African Books Collective.

Pedersen, Morten Axel. 2012. "Common Nonsense: A Review Of Certain Recent Reviews of the 'Ontological Turn.'” Anthropology of This Century 5. http:// aotcpress.com/articles/common_nonsense/.

professor dusky purples. 2018. “Reading Three Ways: Ask Me How!” In Spaces of Spirituality, ed. Nadia Bartolini, Sara MacKian, and Steve Pile, 278-296. London: Routledge.

Ratzan, David M. 2018. "Freakonomika: Oracle as Economic Indicator in Roman Egypt.” In My Lots Are in Thy Hands: Sortilege and Its Practitioners in Late Antiquity, ed. AnneMarie Luijendijk and William E. Klingshirn, 248-289. Leiden: Brill. Schielke, Samuli. 2018. "Destiny as a Relationship." HAU: Journal of Ethnographic Theory 8 (1-2): 343-346. https://doi.org/10.1086/698268. 
Silva, Sónia. 2011. Along an African Border: Angolan Refugees and Their Divination Baskets. Philadelphia: University of Pennsylvania Press.

Silva, Sónia. 2013. "Remarks on Similarity in Ritual Classification: Affliction, Divination, and Object Animation.” History of Religions 53 (2): 151-169. http:// www.jstor.org/stable/10.1086/673184.

Silva, Sónia. 2014. "Mind, Body and Spirit in Basket Divination: An Integrative Way of Knowing.” Religions 5 (4): 1175-1187. https://doi.org/10.3390/rel5041175.

Silva, Sónia. 2018. “Taking Divination Seriously: From Mumbo Jumbo to Worldviews and Ways of Life.” Religions 9 (12): 394-403. https://doi.org/10.3390/ rel9120394.

Sperber, Dan. 1990. “The Epidemiology of Beliefs.” In The Social Psychological Study of Widespread Beliefs, ed. Colin Fraser and George Gaskell, 25-44. Oxford: Clarendon Press.

Stafford, Charles. 2007. "What Is Going to Happen Next?" In Questions of Anthropology, ed. Rita Astuti, Jonathan Parry, and Charles Stafford, 55-76. Oxford: Berg.

Star, Susan Leigh. 2010. "This Is Not a Boundary Object: Reflections on the Origin of a Concept.” Science, Technology, \& Human Values 35 (5): 601-617. https:// doi:10.1177/0162243910377624.

Star, Susan Leigh, and James R. Griesemer. 1989. “Institutional Ecology, 'Translations' and Boundary Objects: Amateurs and Professionals in Berkeley's Museum of Vertebrate Zoology, 1907-39.” Social Studies of Science 19 (3): 387-420. https://doi.org/10.1177/030631289019003001.

Turner, Victor. 1975. Revelation and Divination in Ndembu Ritual. Ithaca, NY: Cornell University Press.

van Beek, Walter E. A. 2015. "Evil and the Art of Revenge in the Mandara Mountains." In Evil in Africa: Encounters with the Everyday, ed. William C. Olsen and Walter E. A. van Beek, 140-156. Bloomington: Indiana University Press.

Viveiros de Castro, Eduardo. 2012. "Cosmological Perspectivism in Amazonia and Elsewhere." Four lectures given in the Department of Social Anthropology, University of Cambridge, February-March 1998. Masterclass Series 1, 45-168. https://haubooks.org/cosmological-perspectivism-in-amazonia/.

Willis, Roy G. 1970. "Instant Millennium: The Sociology of African Witch-Cleansing Cults." In Witchcraft Confessions and Accusations, ed. Mary Douglas, 129-139. London: Tavistock.

Zeitlyn, David. 1990. "Professor Garfinkel Visits the Soothsayers: Ethnomethodology and Mambila Divination.” Man (n.s.) 25 (4): 654-666. https://doi. org/10.2307/2803659.

Zeitlyn, David. 1994. Sua in Somié: Aspects of Mambila Traditional Religion. Sankt Augustin: Academia Verlag.

Zeitlyn, David. 2008. "Life-History Writing and the Anthropological Silhouette.” Social Anthropology 16 (2): 154-171. https://onlinelibrary.wiley.com/ doi/10.1111/j.1469-8676.2008.00028.x.

Zeitlyn, David. 2014. "Lévy-Bruhl and Ontological Déjà Vu: An Appendix to Vigh and Sausdal." Journal of the Anthropological Society of Oxford 6 (2): 213-217. 
https://www.anthro.ox.ac.uk/sites/default/files/anthro/documents/media/ jaso6_2_2014_213_217.pdf.

Zeitlyn, David. 2020a. "Haunting, Dutching, and Interference: Provocations for the Anthropology of Time.” Current Anthropology 61 (4): 495-513. https://doi. org/10.1086/710105.

Zeitlyn, David. 2020b. Mambila Divination: Framing Questions, Constructing Answers. London: Routledge.

Zeitlyn, David, and Roger Just. 2014. Excursions in Realist Anthropology: A Merological Approach. Newcastle upon Tyne: Cambridge Scholars Publishing.

Zempléni, Andras. 1994. "How to Say Things with Assertive Acts? About Some Pragmatic Properties of Senoufo Divination." In Beyond Textuality: Asceticism and Violence in Anthropological Interpretation, ed. Gilles Bibeau and Ellen Corin, 233-248. Berlin: Mouton de Gruyter. 